FACTA UNIVERSITATIS

Series: Physical Education and Sport, Vol. 18, No 1, 2020, pp. 179 - 188

https://doi.org/10.22190/FUPES200222015O

Research article

\title{
PERCEIVED EXERTION AND MODERATE TO VIGOROUS PHYSICAL ACTIVITY IN MIDDLE SCHOOL STUDENTS ACCORDING TO THE PHYSICAL EDUCATION TEACHERS' EXPERIENCE
}

\author{
UDC 796.01
}

\section{Paulina Yesica Ochoa-Martínez, Javier Arturo Hall-López, Cristhian López Campos, Edgar Ismael Alarcón Meza}

Faculty of Sports Autonomous University of Baja California, Mexico

\begin{abstract}
The aim of the current study is to compare the perceived exertion and moderate to vigorous physical activity (PA) among first grade middle school students in physical education (PE) classes given by PE teachers with higher or lower experience than 16 years. Eighty-seven PE lessons conducted by PE teachers with $\geq 16$ years of experience $(n=35)$ and teachers with $<16$ years of experience $(n=52)$ were evaluated by 348 middle school students (Mean age $=12.2 \pm 0.5$ years). To determine the perceived exertion, the pictorial children's effort rating table (PCERT) was completed, after PE. Children chose an option on an illustrated scale 1-10 perceived exertion. The moderate to vigorous physical activity (MVPA) was evaluated using the System for Observing Fitness and Instruction Time (SOFIT) assessing the intensity as the proportion of time that students spent engaged in walking and very active PA during $P E$. A cross-sectional design was used, the equality of variance was calculated using the Student t-test for independent samples resulting in MVPA $(P$-value $=.659)$ and perceived exertion $(P$-value $=.205) \alpha \leq$ than 0.05 . In both groups, the average value of perceived exertion was less than 5 points on the scale, which is insufficient to enhance physical fitness. The MVPA did not achieve international guidelines of engaging students in at least $50 \%$ of the lessons time in walking and very active PA. It is recommended for $P E$ teachers to develop pedagogical strategies contributing from the school environment to guide students in educational contents for health through PA, as established by UNESCO and recommended by the World Health Organization.
\end{abstract}

Key words: Physical Education, Middle School, Perceived Exertion, Teaching Experience

\footnotetext{
Received February 22, 2020/ Accepted April 05, 2020

Corresponding author: Javier Arturo Hall-López

Faculty of Sports of the Autonomous University of Baja California, Avenida Alvaro Obregon Sin Numero,

Colonia Nueva Mexicali, 21100, Baja California, Mexico,

Phone: + 52 (686) 5518200 •E-mail: javierhall@uabc.edu.mx 


\section{INTRODUCTION}

Quality education is part of the sustainable development goals established by the United Nations Organization (UN) for the reduction of extreme poverty in several dimensions (Pérez Betancourt \& Betancourt Rodríguez, 2019). Quality education and investment in health through physical education (PE) area were established by the United Nations Educational, Scientific and Cultural Organization (UNESCO), in its guide for policy makers who work around PE (McLennan \& Thompson, 2015; Frizzo \& Silva Souza, 2019). Metaanalysis and systematic review papers suggest that children and adolescents engaged in regular physical activity (PA) are associated with lower risk of chronic diseases such as obesity (Cvejić, Pejić, \& Ostojić, 2013; Brooke, Corder, Atkin, \& van Sluijs, 2014; Sims, Scarborough, \& Foster, 2015).

The World Health Organization (WHO) recommends accumulating at least 60 minutes of moderate to vigorous physical activity (MVPA) daily (WHO, 2014). In Mexico, the national health survey reports a percentage of physically active girls and boys of $17.2 \%$ and $21.8 \%$ respectively, in schoolchildren aged from 10 to 14 (ENSANUT NM 2016). PE conducted in schools has been highlighted as an educational area to reach most young people to promote a healthy active lifestyle (Kim, 2012; Lonsdale et al., 2013; Langford et al., 2015).

As a conceptual framework in our study, intensity is determined based on energy expenditure and physical effort versus some sort of resistance, thus causing more strain on the body within a specific period of time (Borg, Hassmen, \& Lagerstrom, 1987, Veal \& Campagnone, 1999; Li, 2006; McKenzie \& Van der Mars, 2015). Perceived exertion is related to PA and refers mainly to muscular work that implies tension mostly of the musculoskeletal, cardiovascular, and pulmonary systems; along with motivational and emotional aspects (Borg, 1982).

PE professors should invest all pedagogical and physical effort activities to engage students in pleasurable and fun activities that will induce them to taking part in extra school PA (Shilton, 2008). Additionally, the international guidelines established by the National Association for Sport and Physical Education (NASPE) outlined that students should engage in moderate-to-vigorous PA in at least $50 \%$ of the PE lesson, with activities of energy expenditure similar to walking or running (Banville, 2006; NASPE, 2009).

Research conducted in Mexican elementary schools assessing MVPA in PE lessons using the System for Observing Fitness and Instruction Time (SOFIT) as an instrument (McKenzie, Sallis, \& Nader, 1992), show MVPA in less than 50\% of students (Hall-López, Ochoa-Martínez, Zuñiga, Monreal, \& Sáenz-López, 2017; Hall-López, Ochoa-Martínez, Macías, Zuñiga, \& Sáenz-López, 2018).

In Mexico, the Secretariat of Public Education (SEP for its abbreviation in Spanish) establish PE as part of the mandatory curriculum and students must participate twice a week for 50 minutes per lesson. This model promotes a pedagogical intervention which leads children towards lifelong PA (SEP, 2017).

According to the SEP (2017) teacher experience refers to the years worked as a teacher in the basic education system in Mexico. Teacher experience suggests that environment within which PE lessons are delivered can greatly affect MVPA (Brooke et al., 2014; Hollis et al., 2016). 
Studies correlate the fact that the higher the teacher experience of PE teachers, the higher the intensity of the PE classes (Chow, McKenzie, \& Louie, 2008; Lonsdale et al., 2013; Sutherland et al., 2016).

Therefore, it is hypothesized that more experienced teachers conduct more intensive PE lessons, and the aim of the current study is to compare the perceived exertion and MVPA among first grade middle school students in PE classes given by teachers with experience higher or lower than 16 years.

\section{METHODS}

\section{Participants}

This research was approved and founded by the Autonomous University of Baja California, protocol number 149/2/C/5/21. The study design was a cross-sectional baseline with a non-probabilistic convenience sample (Thomas, Nelson, \& Silverman, 2015). Data were collected through August and December 2019, and PE teachers were evaluated from public middle schools located in the urban area of Mexicali Baja California, Mexico. The study followed the ethical principles regarding human experimentation proposed by the Helsinki declaration (Puri, Suresh, Gogtay, \& Thatte, 2009).

Eighty-seven PE lessons conducted by 87 teachers were divided into two groups: the first group $(n=35)$ consisted of PE teachers with $\geq 16$ years of experience (an average of 22.7 \pm 3.6 years ranging from 16 to 33 years of working in the Secretariat of Public Education) and the second group $(n=52)$ consisted of PE teachers with $<16$ years of experience (an average of $12.7 \pm 2.9$ years ranging from 1 to 15 years of working in the Secretariat of Public Education). Lessons were evaluated by 348 first grade middle school students (Mean age $\pm \mathrm{SD}=12.2 \pm 0.5$ years).

We set as a cutoff point of 16 years of experience because the retirement age among men is 32 years of teacher service and among women 30 years.

\section{Procedures}

Perceived exertion was determined by means of the Pictorial Children's Effort Rating Table (PCERT) developed by Yelling, Lamb and Swaine (2002) based on Borg's CR-10 scale (Borg, 1982). Adjusting it to the cognitive development of the children, figures have been added to the scale, making it more appropriate to choose the option of a representative value for the age of the children. The scores ranged from 1 to 10 with a median value corresponding to 5. This instrument is translated and validated into Spanish and the application of the scale was performed immediately for the four same PE students evaluated by SOFIT after the PE class was finished, and in the same facilities of the elementary school (Hernández-Alvarez, del-Campo-Vecino, Martínez-de-Haro, \& Moya-Morales, 2010).

In order to determine the MVPA during PE lessons, the System for Observing Fitness Instruction Time (SOFIT) was used. SOFIT is an objective tool for assessing the quality of PE instruction that provides a measure of student activity levels and has been calibrated using heart rate monitors and validated using accelerometers, and used in many PE studies (Mckenzie et al., 2002; McKenzie \& van der Mars, 2015). Six data collectors were trained following the standard of the SOFIT protocol, memorizing operational definitions of codes and learning tactical procedures. 
Reliability measures were taken in $100 \%$ of the PE lessons observations (Kappa statistics 0.87). Interpretation of Kappa was according to the following scale: excellent 1.00-0.81; good $0.80-0.61$; moderate $0.61-0.40$; weak $0.40-0.21$; and absence of agreement $0.20-0$, when compared to the trained observers and the chance of agreement in relation to the reference data collector according to Szklo and Nieto (2007).

Using the procedures outlined in the SOFIT manual, onset of the PE lessons, trained observers randomly selected 4 students ( 2 boys and 2 girls). Observers recorded MVPA using a time-sampling system of 10-seconds of observing and 10-seconds of recording intervals while being paced by audio prompts from mp3 player. The coded intensity of PA was scored as 1 =lying down; $2=$ =sitting; $3=$ =standing; $4=$ =walking; $5=$ very active. To identify moderate-to-vigorous PA the codes $4=$ walking and 5=very active were combined as the proportion of time.

\section{Statistical analysis}

The data analysis was performed using the Statistical Package for Social Sciences (SPSS) version 23.0 for Windows (IBM Corporation, New York, USA), by calculating the descriptive values of the variables. In order to verify the normality of the groups and the data variables, the Kolmogorov-Smirnov test was used (degree of significance P-value $\geq 0.05$ ). In order to compare fixed variables of two groups of teachers with different years of experience, with the numerical random variables being perceived exertion and MVPA, parametric statistics were used: the Student t-test for independent samples. Significance was set at $\alpha \leq 0.05$, i.e. $5 \%$ as a percentage of error of the statistical test.

\section{RESULTS}

Descriptive statistics of 87 PE lessons assessed by SOFIT in middle school students can be seen in Table 1 .

Table 1 Descriptive statistics for the sample $(\mathrm{n}=87)$

\begin{tabular}{lrrrr}
\hline Variables & Mean $^{*} \pm$ & SD & Mean $^{* *} \pm$ & SD \\
\hline Lying Down (\%) & $4.1 \pm$ & 1.3 & $3.9 \pm$ & 1.2 \\
Sitting (\%) & $17.6 \pm$ & 4.3 & $16.7 \pm$ & 3.7 \\
Standing (\%) & $41.7 \pm$ & 13.3 & $42.6 \pm$ & 11.2 \\
Walking (\%) & $23.9 \pm$ & 9.5 & $25.2 \pm$ & 11.1 \\
Very Active (\%) & $12.7 \pm$ & 3.1 & $11.6 \pm$ & 4.7 \\
onducted by teachers with $\geq 16$ years of experience ( $\mathrm{n}=35$ measurements); \\
teachers with < 16 years of experience ( $\mathrm{n}=52$ measurements); SD - Standard Deviation.
\end{tabular}

** conducted by teachers with $<16$ years of experience $(n=52$ measurements); SD - Standard Deviation.

The perceived exertion of students who participated in PE classes taught by PE teachers with more than 16 years of practice had a value of $4.9 \pm 1.3$, while in the case of PE teachers with less than 16 years of practice this value was $4.7 \pm 1.6$.

Percentage expression of the PE class duration in minutes in the 35 PE classes taught by PE teachers with more than 16 years of experience was $36.6 \pm 5.1 \%$ (range 22-49) and in the $52 \mathrm{PE}$ classes of PE teachers with less than 16 years of experience was $36.8 \pm 5.0 \%$ (range 28-51). 
The Kolmogorov-Smirnov test resulted in a $\mathrm{P}$ value $\geq 0.05$, indicating normality of groups and variance homogeneity of the data [resulting in perceived exertion (.376) and MVPA (.659) in classes taught by PE teachers with more than 16 years of experience and perceived exertion (.205) and MVPA (.172) in classes taught by PE teachers with less than 16 years of experience]. Variance between the mean and standard deviation (SD) of the variables studied in PE classes taught by PE teachers according to years of experience was calculated using the Student t-test for independent samples. This resulted in a significance level of $\mathrm{P}$ higher than $0.05 \alpha \leq$ in perceived exertion (.562) and MVPA (.374) respectively (Figures 1 and 2).

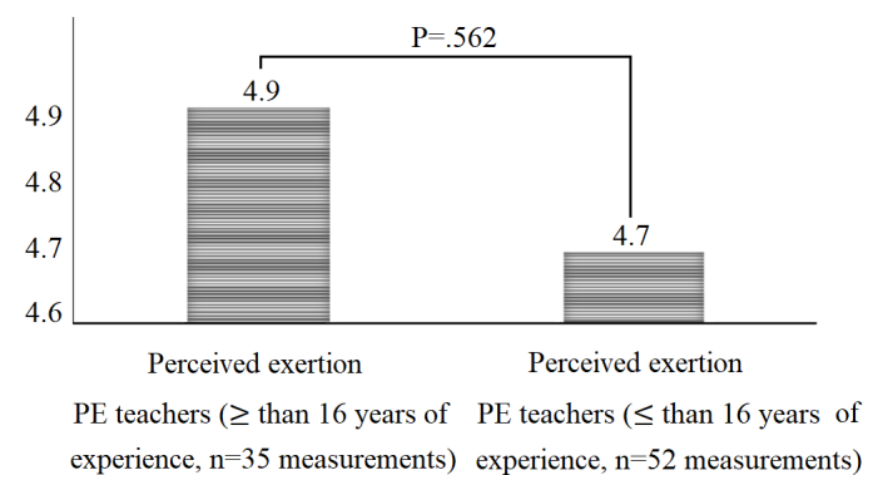

Fig. 1 Mean of Perceived exertion of middle school students in PE classes and variance between two groups

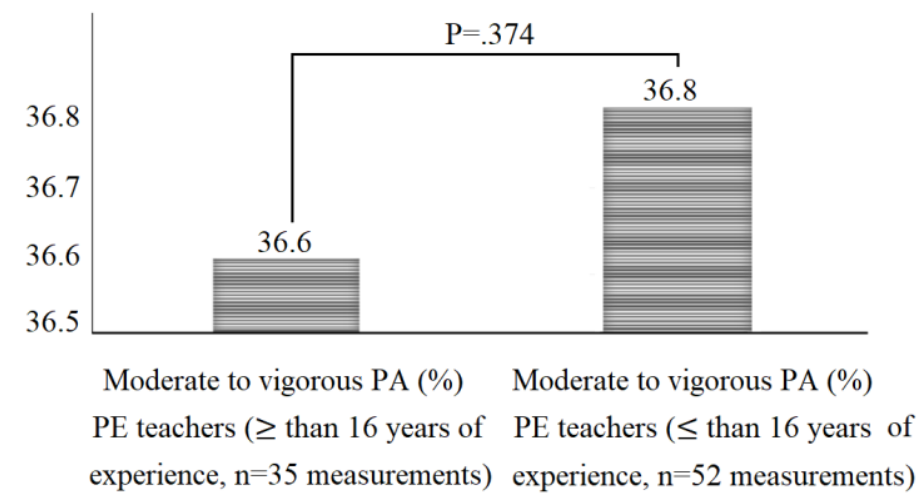

Fig. 2 Mean of $\%$ of Moderate to vigorous Physical Activity (MVPA) of middle school students in PE classes and variance between two groups 


\section{DISCUSSION}

It is hypothesized that more experienced teachers conduct PE lessons with more intensity (Chow et al., 2008; Lonsdale et al., 2013; Sutherland et al., 2016).

However, the main result of this study is that the significant differences in perceived exertion and MVPA among first grade middle school children in PE classes given by teachers with years of experience lower or higher than 16 were not determined.

These values of \% MVPA were similar to related studies carried out in Mexico, in a similar sociodemographic context, using the SOFIT measurement protocols for PE classes conducted in public education (Hall-López, Ochoa-Martínez, Zuñiga, Monreal, \& Sáenz-López, 2017; Hall-López et al., 2018).

According to our results, neither of the two groups reached the internationally established standards set by the NASPE, recommending that PE lessons engage students in MVPA for at least 50\% of the PE lesson (Banville, 2006; NASPE, 2009).

The reasons for the differences in PA participation during PE can be influenced by the environment, such as equipment, class size, teacher credentials, facilities, the scheduled lesson, length and the number of lessons provided per week (Story et al., 2009; Brooke et al., 2014; Salazar et al., 2015; Hollis, Nanney, \& Schwartz, 2016).

PCERT as an alternative pedagogical assessment tool is seeking to contribute towards children's recommended level of PA and to help them understand how to self-regulate their activity (Yelling et al., 2002). In both groups within the actual study the PCERT average value was less than 5 points on the scale. It should be taken into account that values equal to or greater than 5 represent a heart rate above 150 beats per minute (Cowden \& Plowman, 1999). Our result should be considered insufficient to produce the necessary adjustments for better organ function resulting from PA. The data from our study is consistent with other research involving school-age children (Hernandez et al., 2010, Hall-López et al., 2017b).

Regarding years of teacher experience, Griffey and Housner (1991) found that experienced PE teachers ask many more questions before they began planning in comparison to inexperienced PE teachers. In addition, experienced PE teachers' plans reflect a concern about contingencies that might arise during instruction, whereas inexperienced PE teachers' plans do not. Those are the reasons why student engagement shows a marked difference between experienced and inexperienced PE teachers.

Macdonald (1999) investigated whether experienced PE teachers perceive the same frustrations and negative orientations as inexperienced PE teachers. His data suggest that in many respects their working conditions and orientations are more supportive and positive than those reported for inexperienced PE teachers.

The Teacher's Behavior and the intensity of PA have reported where in PE $90.6 \%$ of time the teacher did not promote effort (Retamal-Valderrama, Delgado Floody, EspinozaSilva, \& Jerez-Mayorga, 2019). Wadsworth, Robinson, Rudisill, \& Gell (2013) report that PE teachers who approach a motivational climate allow children to spend more time in MVPA compared to PE teachers who approach a performance-oriented climate. These results highlight the importance of teaching adjustment, as implement strategies, materials, and content to ensure quality in the movement related to the PE curricula (Jovanović \& Minić, 2018).

It has been shown that greater time scheduled in PE does not necessarily result in more student accrual of MVPA minutes (Smith, Monnat, \& Lounsbery, 2015). 
Kwon, Welch, \& Mason (2020), report an association of motor content in PE teacher's in-class and higher promotion of PA. Fun and interesting teaching content was significantly and inversely associated with a MVPA contribution in PE (Cvejić, Buišić, Mitrović, \& Ostojić, 2018).

Additionally, appropriate work organization and contemporary inclusion of all the children into the exercise process and decrement in the loss of time during setting up the formation and explaining simpler content enhance the aerobic capacity in students, through specific tasks that will help students to improve healthy living habits (Hall-López et al., 2017; Guijarro-Romero, Mayorga-Vega, Casado-Robles, \& Viciana, 2019; López-Taveras, \& Moya-Mata, 2019).

Teacher training has been successful in achieving moderate PA in PE; studies with an intervention design show that a well-designed specialist targets decrement in sedentary time in PE (Rosenkranz et al., 2012; Carson et al., 2014; Telford, Olive, Cochrane, Davey, \& Telford, 2016).

\section{CONCLUSIONS}

Limited by the design, our cross-sectional study prevents us from inferring causality. In addition, it was conducted on a sample of PE teachers limited to Mexicans who conduct a curriculum in a pedagogical model of competencies. Despite these limitations, the results presented here allow us to better understand potential restrictions when the PE lessons without strategies for involving the students in MVPA are concerned. The measurement instruments used in the research have a low cost and are easy to apply in large samples. They are valid and offer a non-invasive means to measure the intensity and perceived exertion in PE, as well as provide educational support for PE teachers within the context. PE teachers might find it useful to design proposals aimed at increasing the PA level among adolescents, for at least $50 \%$ of class time regardless of years of experience, respecting the recommendations for children and adolescents established by the WHO for the achievement of a minimum of 60 minutes of PA in a day of moderate to vigorous intensity. This is how quality education and investment in health through PE principles established by UNESCO should be promoted.

\section{REFERENCES}

Banville, D. (2006). Analysis of exchanges between novice and cooperating teachers during internships using the NCATE/NASPE standards for teacher preparation in physical education as guidelines. Research Quarterly for Exercise and Sport, 77(2), 208-221.

Borg, G.A. (1982). Psychophysical bases of perceived exertion. Medicine \& Science in Sports \& Exercise, 14(5), 377-381.

Borg, G., Hassmen, P., \& Lagerstrom, M. (1987). Perceived exertion related to heart rate and blood lactate during arm and leg exercise. European Journal of Applied Physiology and Occupational Physiology, 56(6), 679-685.

Brooke, H.L., Corder, K., Atkin, A.J., \& van Sluijs, E.M. (2014). A systematic literature review with metaanalyses of within-and between-day differences in objectively measured physical activity in school-aged children. Sports Medicine, 44(10), 27-38.

Carson, R.L., Castelli, D.M., Pulling Kuhn, A.C., Moore, J.B., Beets, M.W., Beighle, A., et al. (2014). Impact of trained champions of comprehensive school physical activity programs on school physical activity offerings, youth physical activity and sedentary behaviors. Preventive Medicine, 69 (1), 12-19. 
Chow, B.C., McKenzie, T.L., \& Louie, L. (2008). Children's physical activity and environmental influences during elementary school physical education. Journal of Teaching in Physical Education, 27(1), 38-50.

Cowden, R.D., \& Plowman, S.A. (1999). The self-regulation and perception of exercise intensity in children in a field setting. Pediatric Exercise Science, 11(1), 32-43.

Cvejić, D., Pejović, T., \& Ostojić, S. (2013). Assessment of physical fitness in children and adolescents. Facta Universitatis Series Physical Education and Sport, 11(2), 135-145.

Cvejić, D., Buišić, S., Mitrović, N., \& Ostojić S. (2018). Aerobic activity of students during physical education fitt classes. Facta Universitatis Series Physical Education and Sport, 16, (3). 515-524.

Encuesta Nacional de Salud y Nutrición Medio Camino 2016 (ENSANUT MC 2016) data revisited (n.d.). Retrieved September 17, 2019, from the World Wide Web: http://ensanut.insp.mx/

Frizzo, G., \& Silva Souza, M. (2019). Educação física nas diretrizes da unesco: o paradigma da aptidão física e da saúde na formação do capital humano (Physical education in unesco guidelines: the paradigm of physical fitness and health in the formation of human capital). Movimento, Porto Alegre, 25: e25022, 112. DOI: https://doi.org/10.22456/1982-8918.76037. In Portuguese

Griffey, D.C., \& Housner, L.D. (1991). Differences between experienced and inexperienced teachers' planning decisions, interactions, student engagement, and instructional climate. Research Quarterly for Exercise and Sport, 62(2), 196-204.

Hall-López, J.A., Ochoa-Martínez, P.Y., Zuñiga, R., Monreal, L.R., \& Sáenz-López, P. (2017). Moderate-tovigorous physical activity during recess and physical education among mexican elementary school students. Retos, 31, 137-139.

Hall-López, J. A., Ochoa-Martínez, P. J., Macías, R. A., Zuñiga, R., and Sáenz-López, P. (2018). Actividad física moderada a vigorosa en educación física y recreo en estudiantes de primaria y secundaria de la frontera México-USA (Moderate to vigorous physical activity in physical education and recreation in primary and secondary students of the Mexico-USA border). Sportis: Revista Técnico-Científica del Deporte Escolar, Educación Física y Psicomotricidad, 4(3), 426-442. In Spanish

Hall-López, J.A., Ochoa-Martínez, P.Y., Meza Correa, F., López Campos, C.E., \& Sáenz-López Buñuel, P. (2017). Actividad física y percepción de esfuerzo por género en educación física y recreo de escolares mexicanos (Physical activity and perception of effort by gender in physical education and recreation of Mexican schoolchildren). Educación Física y Deporte, 36(2), 1-9. In Spanish

Hernández-Álvarez, J.L., del-Campo-Vecino, J., Martínez-de-Haro, V., \& Moya-Morales, J.M. (2010). Perception of exertion in physical education and its relationship to guidelines on physical activity. Revista Internacional de Medicina y Ciencias de la Actividad Fisica y del Deporte, 10(40), 609-619.

Hollis, J.L., Williams, A.J., Sutherland, R., Campbell, E., Nathan, N., Wolfenden, L., et al. (2016). A systematic review and meta-analysis of moderate-to-vigorous physical activity levels in elementary school physical education lessons. Preventive Medicine, 86, 34-54.

Jovanović, M., \& Minić, V. (2018). Teachers of physical education on improving the quality of teaching with continuous adjustments to the curricula. Facta Universitatis, Series Physical Education and Sport, 16,(3). 651-661.

Kim, J. (2012). Are physical education-related state policies and schools' physical education requirement related to children's physical activity and obesity? Journal of School Health, 82(6), 268-276.

Kwon, S., Welch, S., \& Mason, M. (2020). Physical education environment and student physical activity levels in low-income communities. BMC Public Health, 20(1), 147.

Langford, R., Bonell, C., Jones, H., Pouliou, T., Murphy, S., Waters, E., et al. (2015). The World Health Organization's Health Promoting Schools framework: a Cochrane systematic review and meta-analysis. BMC Public Health, 15(1), 130.

Li, W. (2006). Understanding the meaning of effort in learning a motor skill: Ability conceptions. Journal of Teaching in Physical Education, 25(3), 298-309.

Lonsdale, C., Rosenkranz. R.R., Peralta, L.R., Bennie, A., Fahey, P., \& Lubans, D.R. (2013). A systematic review and meta-analysis of interventions designed to increase moderate-to-vigorous physical activity in school physical education lessons. Preventive Medicine, 56(2),152-61.

Macdonald, D. (1999). The "professional" work of experienced physical education teachers. Research Quarterly for Exercise and Sport, 70(1), 41-54.

McKenzie, TL., \& van der Mars, H. (2015). Top 10 research questions related to assessing physical activity and its contexts using systematic observation. Research Quarterly for Exercise and Sport, 86(1), 13-29.

McKenzie, T.L. (2002). System for Observing Fitness Instruction Time. Overview and training manual. San Diego, CA: San Diego State University.

Mckenzie, T.L., Sallis, J.F., \& Nader, P.R. (1992). Sofit-System for Observing Fitness Instruction Time. Journal of Teaching in Physical Education, 11(2), 195-205. 
McLennan, N., \& Thompson, J. (2015). Libro: Educación física de calidad (EFC): Guía para los responsables políticos (Book: Quality Physical Education (QPE): a Guide for Policymakers). United Nations Educational, Scientific and Cultural Organization-UNESCO 2015. Retrieved September 25, 2019, from the World Wide Web: https://unesdoc.unesco.org/ark:/48223/pf0000231340

National Association for Sport and Physical Education-NASPE (2009). The national standards guidelines and position statements, E.U.A; 2009. Population. Retrieved September 17, 2019, from the World Wide Web: http://www.aahperd.org/naspe/

Pérez Betancourt, A., \& Betancourt Rodríguez, M.Z. (2019). El enfoque de género desde la formación docente y su relación con la ciencia, la tecnología y la sociedad (The gender approach from teacher training and its relationship with science, technology and society). Revista Boletín Redipe, 8(3), 200-208. In Spanish

Puri, K.S., Suresh, K.R., Gogtay, N.J., \& Thatte, U.M. (2009). Declaration of Helsinki implications for stakeholders in research. Journal of Postgraduate Medicine, 55(2), 131-134.

Retamal-Valderrama, C., Delgado Floody, P., Espinoza-Silva, M., \& Jerez-Mayorga, D. (2019). Comportamiento del profesor, intensidad y tiempo efectivo de las clases de educación física en una escuela pública: Un acercamiento a la realidad (Teacher's behavior, intensity and effective time of physical education classes in a public school: An approach to reality. Retos, 35, 160-163. In Spanish

Rosenkranz, R.R., Lubans, D.R., Peralta, L.R. Bennie, A., Sanders, T., \& Lonsdale, C. (2012). A clusterrandomized controlled trial of strategies to increase adolescents' physical activity and motivation during physical education lessons: the Motivating Active Learning in Physical Education (MALP) trial. BMC Public Health, 12(834), 1-9.

Salazar, C.M., Gómez-Figueroa, J.A., Pérez, M.P., Vargas, C.S., Flores-Moreno, P.J., Medina-Valencia, R., T., et al. (2015). Vocational training and basic knowledge of the Mexican University coach. Sociology Study, 5(3), 232-244.

Secretaria de Educación Pública-SEP (2017). Aprendizajes clave para la educación integral. Educación física. Educación básica. Plan y programas de estudio y sugerencias de evaluación. Primera edición, 2017 (Key learnings for comprehensive education. Physical education. Basic education. Study plan and programs and evaluation suggestions. First edition, 2017). México City. Retrieved September 20, 2019, from the World Wide Web: https://www.aprendizajesclave.sep.gob.mx/. In Spanish

Sims, J., Scarborough, P., \& Foster, C. (2015). The Effectiveness of Interventions on Sustained Childhood Physical Activity: A Systematic Review and Meta-Analysis of Controlled Studies. PLoS One, 20;10(7):e0132935. doi: 10.1371/journal.pone.0132935. eCollection 2015.

Shilton, T. (2008). Creating and making the case: Global advocacy for physical activity. Journal of Physical Activity \& Health, 5(6), 765-776.

Smith, N.J., Monnat, S.M., \& Lounsbery, M.A. (2015). Physical activity in physical education: are longer lessons better?. The Journal of School Health, 85(3), 141-148.

Szklo, M., \& Nieto, J. (2007). Epidemiology: Beyond the basics (2nd ed.). Jones \& Bartlett Learning.

Story, M., Nanney, M.S., \& Schwartz, M.B. (2009). Schools and obesity prevention: Creating school environments and policies to promote healthy eating and physical activity. Milbank Quarterly, 87(1), 71-100.

Sutherland, R., Campbell, E., Lubans, D.R., Morga, P.J., Okely, A.D., Nathan N., et al. (2016). Physical education in secondary schools located in low-income communities: Physical activity levels, lesson context and teacher interaction. Journal of Science and Medicine in Sport, 19(2), 135-141.

Telford, R.M., Olive, L.S., Cochrane, T., Davey, R., \& Telford, R.D. (2016). Outcomes of a four-year specialist-taught physical education program on physical activity: a cluster randomized controlled trial, the LOOK study. International Journal of Behavioral Nutrition and Physical Activity, 13(1), 64.

Thomas, J.R., Nelson, J.K., \& Silverman, S.J. (2015). Research methods in physical activity (7th. Ed.). Champaign, Ilinois: Human Kinetics.

Veal, M.L., \& Campagnone, N. (1995). How sixth graders perceive effort and skill. Journal of Teaching in Physical Education, 14(4), 431-444.

Wadsworth, D.D., Robinson, L.E., Rudisill, M.E., \& Gell, N. (2013). The effect of physical education climates on elementary students' physical activity behaviors. The Journal of School Health, 83(5), 306-313.

World Health Organization-WHO (n.d.). Global Strategy on Diet, Physical Activity and Health, Physical Activity and Young People, Recommended levels of physical activity for children aged 5 - 17 years; Retrieved January, 9, 2019 from the World Wide Web: http://www.who.int/dietphysicalactivity/factsheet_young_people/en/

Yelling, M., Lamb, K.L., \& Swaine, I.L. (2002). Validity of a pictorial perceived exertion scale for effort estimation and effort production during stepping exercise in adolescent children. European Physical Education Review, 8(2), 157-175. 


\section{OPAŽENI NAPOR I UMERENA DO SNAŽNA FIZIČKA AKTIVNOST SREDNJOŠKOLACA NA OSNOVU ISKUSTVA NASTAVNIKA FIZIČKOG VASPITANJA}

Cilj istraživanja je da se uporede opaženi napor i umerena do snažna fizička aktivnost (FA) učenika prvog razreda srednjih škola na nastavi fizičkog vaspitanja koju drže nastavnici fizičkog vaspitanja sa iskustvom većim ili manjim od 16 godina. Osamdeset i sedam sati nastave fizičkog vaspitanja koje su sproveli nastavnici $s a \geq 16$ godina iskustva $(n=35)$ i nastavnici sa $<16$ godina iskustva $(n=52)$ ocenjeni su od strane 348 srednjoškolaca (prosečne starosti $12.2 \pm 0.5$ godina). Da bi se utvrdio opaženi napor, nakon nastave fizičkog vaspitanja popunjena je PCERT tabela dečjeg napora u kojoj deca biraju opciju opaženog napora na ilustrovanoj skali od 1 do 10. Umerena do snažna fizička aktivnost (MVPA) procenjena je korišćenjem Sistema za posmatranje fitnesa $i$ vremena instrukcije (SOFIT) ocenjivanjem intenziteta kao dela vremena u odnosu na učenike koji hodaju $i$ vrlo su fizički aktivni tokom nastave fizičkog vaspitanja. U istraživanju transferzalnog karaktera jednakost varijanse je izračunata pomoću Student t-testa za nezavisne uzorke koji su rezultirali sa MVPA (P-vrednost=.659) $i$ opaženim naporom $(P$-vrednost $=.205) a \leq$ od $0.05 . U$ obe grupe, prosečna vrednost opaženog napora bila je manja od 5 bodova na skali, što je nedovoljno za poboljšanje fizičke spremnosti. MVPA nije ispunila međunarodne smernice o uključivanju učenika $u$ hodanje $i$ vrlo aktivnu fizičku aktivnost najmanje 50\% nastavnog vremena. Nastavnicima fizičkog vaspitanja se preporučuje da razviju pedagoške strategije koje doprinose usmeravanju učenika prema obrazovnim sadržajima i zdravlju putem FA, u skladu sa preporukama UNESCO i Svetske zdravstvene organizacije.

Ključne reči: fizičko vaspitanje, srednja škola, opaženi napor, nastavničko iskustvo 